\title{
Analysis of Student's Critical Thinking Ability Through Application of Cooperative Learning Models Jigsaw in Global Prima High School Medan
}

\author{
Tri Dwi Larosa Simanjuntak ${ }^{1}$, Asrin Lubis ${ }^{2}$, Mulyono $^{3}$ \\ State University of Medan, J1. Willem Iskandar Psr. V Medan, Indonesia
}

\begin{abstract}
This purpose of this study are to analyze students' critical thinking skills and mathematical disposition through the application of Jigsaw cooperative learning models, including (1) students' critical thinking abilities and mathematical disposition taught by using Jigsaw type cooperative learning models, (2) students' critical thinking skills in terms of disposition mathematical students in learning, (3) indicators of critical thinking and mathematical disposition which are dominantly increased in learning and (4) student difficulties in terms of indicators of critical thinking and mathematical disposition after learning. The subjects in this study were 32 students of X-IPA 1 of the Global Prima National Plus School in Medan and the object of this study was the ability to think critically and students' mathematical dispositions. This research is a qualitative descriptive study. The instruments used consisted of tests of critical thinking skills, mathematical disposition questionnaires, interview guidelines.
\end{abstract}

Keywords: Critical Thinking Ability, Mathematical Disposition, Cooperative Learning Model Jigsaw DOI: $10.7176 / \mathrm{JEP} / 11-15-19$

Publication date:May $31^{\text {st }} 2020$

\section{PRELIMINARY}

The progress of Science and Technology (IPTEK) and the current rapid globalization as a result of changes and discoveries in developed countries. The development of this era has demanded us to participate in world competition by preparing students to be able to face the changing circumstances in daily life that always develop through the practice of acting on the basis of logical, rational, critical, careful, honest, efficient and effective thinking (Darmawan.2016: 1). Karisa (2014: 3) states "Education has a responsibility in realizing quality human resources, especially preparing students as the successors of future development that are competent, independent, critical, creative and able to solve the problems they face".

According to Sugiyono (2009: 65) education is one measure of the progress of a nation. Therefore it is very important to pay attention to the progress of education in our country. Education is really needed to create the next generation of the nation that is qualified and has skills. The statement was made clear by the opinion of Sanjaya (2009: 55) which said that "education has a very important role in human survival and the development of a nation." Thus the way someone thinks becomes more critical.

Mathematics is one of the sciences that has an important role in preparing students as the successors of future development (Buchori.2015: 371). There are several responses to mathematics according to Yakin Telaumbanua (2017: 73) namely, mathematics according to Wittgenstein is "nothing but a method of logical thinking", and according to Bertrand Russell, "mathematics is a period of logical maturity, whereas logic is a childhood of mathematics". From this description, it is clear that mathematics is very important to be learned, developed and mastered in the field of education such as in schools. So mathematics lessons in school are expected to be learned correctly and precisely in the learning process so that the benefits of mathematics can really be used and applied in students' lives.

The most recent results, the 2011 TIMSS study published by the IEA (2012: 42), "Indonesia ranked 38 th out of 42 participating countries with an average score of 386, while the International average score of 500". The TIMSS study results show that Indonesia's ranking is still far from what was expected. Trends Data International Mathematics Education (TIMSS) in 2015 (IEA.2016), Indonesia ranked 45 out of 50 participating countries with a score of 397 points, it is still below the international average score of 50 points. In the results of the study, Indonesian students were weak in all aspects of content and cognitive.

This condition is not much different from the results of a study conducted by PISA (Program for International Student Assessment) published by the Ministry of Education and Culture "The results of the 2006 PISA study, Indonesia ranked 50th out of 57 participating countries with an average score of 391 , while the score international average 500 ". The results of the 2009 PISA study published by the 
OECD (2010: 155), "Indonesia is ranked 61 out of 65 participating countries with an average score of 371 , while the international average score is 500". The results of the 2012 PISA study were re-published by the OECD (2013: 65), "Indonesia is ranked 64th out of 65 participating countries with an average score of 375 , while the international average score is $500 "$. From these results it can be concluded that in achieving international standard mathematical value standards such as PISA and TIMSS it is necessary to apply mathematics learning with critical thinking processes in completing it.

Critical thinking which includes the ability to analyze, draw conclusions, make interpretations, explanations, self-regulation, curiosity, systematic, wise search for truth, and confidence in the thought process carried out is needed by someone in an effort to solve a problem [7]. Johnson (2010: 100) says that, "critical thinking is needed in mental activities such as problem solving, decision making, analyzing assumptions, and scientific discoveries. For this reason, critical thinking skills are very important for students to have. " The same thing was also stated by Ennis (in Ikashaum, 2016: 2) that, "critical thinking is needed to ensure the extent to which a problem can be defined specifically so that several criteria are obtained as a reference for solving the problem."

Several studies on critical thinking report that although they have not achieved good results through learning that gives students the opportunity to think, students' critical thinking skills are better than conventional learning. Innabi (in Sumarmo.2011:27) reports that in her observation of the learning process of 38 junior high school mathematics teachers in Amman, Jordan, only a small portion of all teacher teaching activities contained activities to develop aspects of critical thinking in mathematics.

Research related to critical thinking skills was also conducted by Hidayati (2016: 121). In his research, data was obtained that from 40 people who were made into research objects and given 4 mathematical problems, only 14 students $(35 \%)$ were able to complete the 4 problems given. However, out of the 4 questions, only 3 students were able to solve the 4 questions correctly and the correct solution and 11 other people answered incorrectly. While 26 students $(65 \%)$ in the class could not complete all the questions given and there were no correct answers. In this case it can be said, students' critical thinking skills are still very low.

This is also in line with preliminary studies that have been conducted by researchers at the Global Prima Medan High School to find out the students' initial abilities in mathematical critical thinking at the school. The following is one of the tests of critical thinking skills given by researchers.

1. Determine the results of $\left(-2^{-2}\right)^{3}:\left(-3 a^{-2}\right)$.

2. Determine the value of $x$ in $\log \mathrm{x}+\log 5=0$.

\section{Figure 1.1. Test Questions for Critical Thinking Ability}

The following is one of the students 'answers which shows that the students' mathematical critical thinking skills obtained are still low.

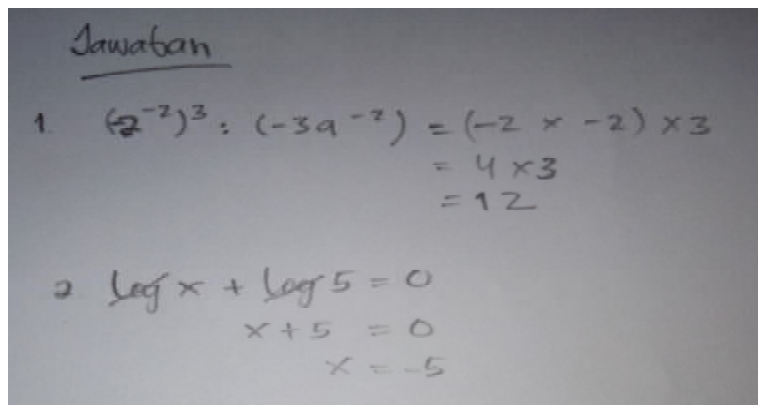

Figure 1.2. Student Answers in Solving Problems Students' Critical Mathematical Thinking Abilities 
Based on student answer number 1, it appears that students are only able to identify questions but are unable to generalize, analyze and evaluate questions. In this case, there is no visible fulfillment of the ability of mathematical critical thinking indicators. Students are not able to use the concept of dividing two rank numbers, unable to calculate the division of two numbers and are unable to prove the results obtained are true. Whereas in the proof of question number 2, students are not able to solve problems regarding the sum of logarithms. Student answers also do not meet the indicators that should be. Students are not able to apply the concept of the sum of logarithms, calculate them and prove the known data from the answers they get. From the two answers given by these students, it can be concluded that the students' critical thinking skills are still very low.

In the opinion of Mahmuzah (2014: 49), the low ability of students to think critically mathematically is also caused by the teacher not being able to create creative, fun and active learning, the teacher is not familiar with the types of learning models and lacks mastery of technology. Likewise in the Global Prima National Plus School High School, as students, students can not be invited to think critically when confronted with math problems. Most students immediately give up or prefer not to continue the answer rather than having to struggle to solve the problem.

From the description above, the difficulty of students in learning to make students' critical thinking skills is relatively low, therefore efforts in mathematics learning are needed. One learning that is assumed to be able to improve students' mathematical critical thinking skills is through the Jigsaw cooperative learning model.

\section{LITERATURE REVIEW 2.1 Critical Thinking Ability}

Ennis (in Ristanti, 2017: 37) argues that critical thinking is a reflective thinking process that focuses on deciding what is believed to be done. This means that someone who thinks critically will be able to process their thoughts and behavior to act in terms of what really needs to be done to solve a problem. Correspondingly, Mahmuzah (2014: 44) states that "critical thinking is a thought that is focused on deciding what is believed to be done". Thus critical thinking considers and evaluates information that ultimately enables students to actively make decisions. The same thing was conveyed by Schafersman (in Ristanti. 2017: 40) that critical thinking is thinking in accordance with relevant and reliable knowledge. A person who thinks critically can ask the right questions, gather relevant information, efficiently and creatively sort out information, and arrive at conclusions that can be trusted and which enable a person to live and act successfully in his life.

Facione (2013: 5) states that there are six indicators of critical thinking ability, namely interpretation, analysis, evaluation, inference, explanation, and self-regulation. But in this study, researchers only use indicators of interpretation, analysis, evaluation, and inference.

\subsection{Jigsaw Type Cooperative Learning Models}

In the application of Jigsaw, students are divided into groups consisting of 4-6 heterogeneous students, and work together on positive interdependence and are responsible for completing the portion of the subject matter that must be studied, and delivering the material to other group members.

Jigsaw is designed to increase students' sense of responsibility towards their own learning and also the learning of others. Students not only learn the material given, but they must also be prepared to give and teach the material to other group members. Thus, students are interdependent with each other and must cooperate cooperatively to learn the material assigned. Members from different teams with the same topic meet to discuss (called a team of experts) helping each other about the learning topics assigned to them. Then the students return to the original team / group to explain to other group members what they have learned before at the expert team meeting.

\section{RESEARCH METHOD}

This type of research is quasi-experimental. Based on a descriptive qualitative approach in this study, all written and oral facts from observable human data sources and other related documents are described as they are then reviewed as concisely as possible to answer the problem. This research has been conducted at SMA Global Prima National School Medan. The subjects in this study were 32 students of 
Class X - 1 Science. The object in this study is the ability to think critically mathematically through the application of Jigsaw cooperative learning models. Criteria for taking subjects using criteria is based on indicators of student ability, student error. There are three categories of student answers, namely (1) high-ability students' answer sheets, (2) medium-ability students' answer sheets, (3) low-ability students' answer sheets. Hope the categories are then analyzed and then grouped. Then based on the grouping, the dominant answers are chosen for later interviews. The research instrument was a test of mathematical critical thinking skills and interview guidelines. Data analysis was performed using the Miles and Huberman model.

The analysis process of student answer sheets can be done by referring to the guideline of critical thinking scoring which consists of four indicators and the score information obtained. The scoring guidelines can be seen in the following table.

Table 3.1. Guidelines for Scoring Critical Mathematical Thinking Ability

\begin{tabular}{|c|c|c|}
\hline Indicator & Description & Score \\
\hline \multirow{5}{*}{ Interpretation } & Not writing the known and asked & 0 \\
\hline & Write what is known and what is asked incorrectly & 1 \\
\hline & Just write down what is known correctly or just what is asked correctly & 2 \\
\hline & Write what is known from the problem correctly but is incomplete & 3 \\
\hline & Write what is known and asked of the problem precisely and completely & 4 \\
\hline \multirow{5}{*}{ Analysis } & Not make a mathematical model of the problem given but it is not right & 0 \\
\hline & Make a mathematical model of the problem given but not right & 1 \\
\hline & $\begin{array}{l}\text { Make a mathematical model of the problem given precisely without giving an } \\
\text { explanation }\end{array}$ & 2 \\
\hline & $\begin{array}{l}\text { Make a mathematical model of the problem given precisely but there are errors } \\
\text { in the explanation }\end{array}$ & 3 \\
\hline & $\begin{array}{l}\text { Make a mathematical model of the problem given correctly and give a correct } \\
\text { and complete explanation }\end{array}$ & 4 \\
\hline \multirow{5}{*}{ Evaluation } & Do not use strategy in solving problems & 0 \\
\hline & Using inappropriate and incomplete strategies in solving problems & 1 \\
\hline & $\begin{array}{l}\text { Using the right strategy in solving problems, but not complete or using } \\
\text { strategies that are not right but complete in solving problems }\end{array}$ & 2 \\
\hline & $\begin{array}{l}\text { Use the right strategy in solving problems, complete but make mistakes in } \\
\text { calculations or explanations }\end{array}$ & 3 \\
\hline & $\begin{array}{l}\text { Using the right strategy in solving problems, complete and correct in making } \\
\text { calculations / explanations }\end{array}$ & 4 \\
\hline \multirow{5}{*}{ Inference } & Don't make conclusions & 0 \\
\hline & Make conclusions that are not right and do not fit the context of the problem & 1 \\
\hline & $\begin{array}{l}\text { Making inaccurate conclusions, although adjusted to the context of the } \\
\text { problem }\end{array}$ & 2 \\
\hline & Make conclusions correctly, according to context but not complete & 3 \\
\hline & $\begin{array}{l}\text { Make conclusions precisely, in accordance with the context of the problem and } \\
\text { complete }\end{array}$ & 4 \\
\hline
\end{tabular}

Modification from Facione (Normaya, 215:93)

To determine whether students meet each of the indicators of critical thinking skills or have not yet solved the problems contained in mathematical problems, it can be seen from the following percentage values.

$$
\text { Percentage value }=\frac{\text { Acquistions score }}{\text { Maximum Score }} \times 100 \%
$$


The percentage value of critical thinking skills obtained from calculations is then categorized according to the following table.

Table 3.2. Categories of Critical Mathematical Thinking Skills

\begin{tabular}{|c|c|}
\hline Tingkat SKBKM & Kriteria \\
\hline $0 \leq$ SKBKM $<50$ & Low \\
\hline $50 \leq$ SKBKM $<80$ & Medium \\
\hline $80 \leq$ SKBKM $<100$ & High \\
\hline
\end{tabular}

Note: SKBKM = Mathematical Critical Thinking

Ability Score

Then proceed with analyzing the difficulties of students in solving mathematical problems after the implementation of learning through the application of Jigsaw Cooperative Learning. Here is a grid of students' difficulties in solving mathematical problems.

Table 3.3. Grid - Difficulty Grid of Critical Mathematical Thinking Processes

\begin{tabular}{|l|l|l|}
\hline \multicolumn{1}{|c|}{ Steps } & $\begin{array}{c}\text { Critical } \\
\text { Thinking } \\
\text { Aspects }\end{array}$ & \multicolumn{1}{|c|}{ Indicator of Difficulty } \\
\cline { 1 - 2 } Problem Orientation & Interpret & $\begin{array}{l}\text { There is a conflict with the } \\
\text { agreement that exists in } \\
\text { mathematics }\end{array}$ \\
\cline { 1 - 2 } Organizing Students for Learning & Analyze & $\begin{array}{l}\text { Wrong operation or } \\
\text { procedure }\end{array}$ \\
\cline { 1 - 3 } Guide Individual or Group Investigations & Evaluate & $\begin{array}{l}\text { Incorrect conclusions or } \\
\text { generalizations }\end{array}$ \\
\hline $\begin{array}{l}\text { Develop and Present Work Results } \\
\text { Process }\end{array}$ & Interfere & \\
\hline
\end{tabular}

\section{RESULTS}

In the learning process carried out during four meetings in the class X - 1 IPA High School Global Prima National Plus School Medan, it was found that students' critical thinking skills improved after the application of Jigsaw cooperative learning compared to conventional learning. This is because each student becomes more active in learning in finding the concept of learning itself through the groups in its path, meaning that students who are divided into expert groups learn from each other the material being shared. Then the student returns to the original group to share what they know so that each student gets all the learning well. Students can interact with each other. For things that are difficult to understand, students can ask the teacher so the problem can be solved.

Based on the explanation above, the Jigsaw cooperative learning model can be used as an alternative learning that can improve students' mathematical critical thinking skills. This can be seen in the following discussion. The following shows the critical thinking skills of students who are supervised directly by researchers and mathematics teachers in the Global Prima Medan High School. 
Table 4.1 Students' Critical Mathematical Thinking Abilities

\begin{tabular}{|c|c|c|c|}
\hline Interval of SKBKM & $\begin{array}{c}\text { Total } \\
\text { students }\end{array}$ & Percentage & Criteria \\
\hline $0 \leq$ SKBKM $<50$ & 8 & $26,67 \%$ & Low \\
\hline $50 \leq$ SKBKM $<80$ & 18 & $60 \%$ & Medium \\
\hline $80 \leq$ SKBKM $<100$ & 6 & $13,33 \%$ & High \\
\hline Highest Score & \multicolumn{3}{|c|}{86} \\
\hline Lowest Score & \multicolumn{3}{|c}{44} \\
\hline Range & \multicolumn{3}{|c}{67,61} \\
\hline Average & \multicolumn{3}{|c}{} \\
\hline Deviation Standard &
\end{tabular}

Based on the above table, it can be seen that the level of mathematical critical thinking ability of students with low judgment categories is 8 people with a percentage of $26.67 \%$. Students with a medium assessment category numbered 18 people with a percentage of $60 \%$, and students with a high assessment category numbered 4 people with a percentage of $13.33 \%$. Meanwhile, to see the percentage of each critical thinking indicator can be seen in the following table.

Table 4.2 Percentage of Each Indicator of Critical Thinking

\begin{tabular}{|c|c|}
\hline Indicator of Critical Thinking & Percentage \\
\hline Interpretation & $66,43 \%$ \\
\hline Analysis & $62,90 \%$ \\
\hline Evaluation & $68,66 \%$ \\
\hline Inference & $67,63 \%$ \\
\hline
\end{tabular}

Based on the table above, it can be concluded that the evaluation indicator is more dominantly mastered by students in completing the critical thinking ability test given by the teacher with $68.66 \%$, while the interpretation indicator of 32 students shows that $66.43 \%$ of students are able to master the indicator, for analysis indicator $62.90 \%$ and indicator inference with a percentage that is $67.63 \%$.

\section{REFERENCES}

Buchori, A. (2015). Development Learning Model Of Charactereducation through E-Comic In Elementary School. International Journal of Education Research. Vol. 3, No. 9, November 2015, Hal 369-386.

Darmawan. (2016). IPTEK dalam Pendidikan Formal. Bandung: Kaifa.

Facione, A. (2013). Critical Thinking: What It Is and Why It Counts. Measured Reasons and The California Academic Press, Millbrae, CA.

Hidayati, N. (2016). Hasil Belajar dan Keterampilan Berpikir Kritis Siswa Madrasah Tsanawiyah dalam Pembelajaran IPA Melalui Kerja Ilmiah. Jurnal Biology Education. Volume 13, Nomor 1, halaman 118 $-127$.

IEA. (2012). TIMSS 2011 internationl result in mathematics. [online]. Tersedia: http://timss.bc.edu/timss2011/downloads/T11 IR M Chapter.pdf. [26 Agustus 2018].

IEA. (2016). Math Student Achivement Infografic Grade 4. TIMSS 2015. Diakses dari http://timss2015.org/download-center.

Ikashaum. (2016). Analisis Kesulitan Belajar Siswa dalam Mata Pelajaran Matematika Pada Materi Peluang Kelas XI IPA SMA Muhammadiyah Meulaboh Johan Pahlawan. Jurnal Pendidikan Matematika. Vol 1, No. 1 
Hal: $1-13$

Johnson, E,B. (2010). Contextual Teaching and Learning: Menjadikan Kegiatan Belajar Mengajar Mengasyikkan dan Bermakna. Bandung: Kaifa.

Karisa, dkk. (2014). Pengaruh Model Pembelajaran Kooperatif Tipe STAD dengan Pendekatan Pemecahan Masalah terhadap Kemampuan Berfikir Kritis Matematis ditinjau dari Penalaran Formal. e-Journal Program Pascasarjana Universitas Pendidikan Ganesha, 3: 1-4.

Mahmuzah, dkk. (2014). Peningkatan Kemampuan Berfikir Kritis dan Disposisi Matematis Siswa SMP dengan Menggunakan Pendekatan Problem Posing. Jurnal Didaktik Matematika. Volume 01, nomor 02, Halaman $43-53$.

OECD. (2010). PISA 2009 result: what student know and can do - student performance in mathematics, reading and science (volume i). [online]. Tersedia: http://www.oecd.org/pisa/keyfindings/pisa-2012-resultvolume-I.pdf. [26 Agustus 2018].

OECD. (2013). PISA 2012 result: what student know and can do - student performance in mathematics, reading and science (volemu i). [online]. Tersedia: http://www.oecd.org/pisa/keyfindings/pisa-2012-resultvolume-I.pdf [26 Agustus 2018].

Ristanti, F. (2017). Kemampuan Berfikir Kritis Ditinjau Dari Disposisi Matematis Siswa SMP Negeri 3 Purwokerto. Journal Of Mathematics Education. Volume 2, Nomor 2, November 2017. 2477-409X. Halaman 36-47.

Sanjaya, W. (2009). Strategi Pembelajaran Berorientasi Standar Proses Pendidikan. Jakarta: Kencana Prenada Media Group.

Sugiyono. (2009). Memahami Penelitian Kualitatif. Bandung: Alfabeta.

Telaumbanua, Y. (2017). Development of Mathematics Module Based on Metacognitive Strategy in Improving Students' Mathematical Problem Solving Ability at High School. Journal of Education and Practice. Vol.8, No.19, 2017 ISSN 2222-1735. Halaman 73-80. 